\title{
Facilitating Sustainable Self-Directed Learning Experience with the Use of Mobile-Assisted Language Learning
}

\author{
Kyeong-Ouk Jeong
}

check for updates

Citation: Jeong, K.-O. Facilitating Sustainable Self-Directed Learning Experience with the Use of

Mobile-Assisted Language Learning. Sustainability 2022, 14, 2894. https:// doi.org/10.3390/su14052894

Academic Editors: Pilar Colás-Bravo and Jesús Conde-Jimenez

Received: 28 January 2022

Accepted: 26 February 2022

Published: 2 March 2022

Publisher's Note: MDPI stays neutral with regard to jurisdictional claims in published maps and institutional affiliations.

Copyright: (C) 2022 by the author. Licensee MDPI, Basel, Switzerland This article is an open access article distributed under the terms and conditions of the Creative Commons Attribution (CC BY) license (https:// creativecommons.org/licenses/by/ $4.0 /)$.
Department of English Education, Graduate School of Education, Hannam University, Daejeon 34430, Korea; monicajko@hnu.kr

\begin{abstract}
This study explored the impact of utilizing mobile-assisted language learning to help EFL university students promote their learning performance and support a sustainable self-directed learning experience while developing digital literacy and technology competence. The global pandemic and spread of COVID-19 have accelerated the convergence of technology in the classroom in response to an emergency where the sustainability of education is at stake. With the progress of digital technology, a variety of smart mobile applications have been applied in English language learning and teaching. The use of those technologies can encourage language learners to practice selfdirected learning beyond the classroom settings, which is essential for motivated and autonomous learning. Mobile phone applications have great potential as effective pedagogical tools with features such as accessibility, manageable interface, and multifunctional components. However, the use of mobile-assisted language learning for sustainable, self-directed learning outside the classroom has been relatively under-researched. In this study, EFL university students engaged in mobile-assisted language learning that could make their learning more sustainable and independent outside of the classroom. The data of this study show that students' attitudes toward participating in mobileassisted English language learning were affirmative. The results show that incorporation of mobile applications into language learning could foster learner motivation and make their learning more sustainable and entertaining than simply using the conventional instructional methods. Participants of this study stated that major benefits of experiencing mobile-assisted learning for their English study were ease of access to learning contents, portability of the learning tools, flexible and self-directed learning environment, better interaction, and improved self-efficacy in English learning performance. The pedagogical implications of the study are discussed, and instructional strategies are suggested to share ideas about a more pertinent learning environment in the era of digital transformation.
\end{abstract}

Keywords: sustainable learning; learning with ICT; mobile-assisted language learning; self-directed learning; EFL

\section{Introduction}

The development of information and communication technology has been changing not only the lifestyle of modern people but also the educational environment at a striking speed. E-learning, which uses computers and the Internet to learn in class, has already become a common learning method, and the development of such information and communication devices provides both teachers and learners with opportunities to experience a new teaching and learning environment [1]. The global pandemic and spread of COVID-19 have accelerated the convergence of technology with the classroom in response to an emergency where the sustainability of education is at stake. With the recent innovative progress in digital technology, the use of digital devices today has penetrated into all aspects of our lives. Recently, mobile phones have become a must-have item for people living in the era of the digital revolution. Mobile phones are equipped with multitask functions such as wireless computer activity, phone function, camera function, memo function, and personal information management function without time and space restrictions. In addition, a lot of 
activities are possible with mobile phones, such as listening to music, watching video clips, using a navigator in driving, taking photos and videos, checking an e-calendar, taking notes, reading an e-book, and playing mobile games. Therefore, it can be said that mobile phones can be utilized as a new educational tool that can accelerate a new type of mobile learning environment [2]. Mobile devices are not only replacing traditional learning tools but are also being recognized as an expanded learning tool for the digital learning environment, which requires new teaching and learning functions [3]. Moreover, the characteristics of portable digital devices enable learner-centered education by enabling cooperative learning through ubiquitous interaction beyond face-to-face relationships in the classroom [4]. Integrating mobile phones in learning and teaching has received favorable responses from both educators and students [5]. Research results show that mobile devices could boost learner motivation, make the learning process more engaging, and help students acquire knowledge in an entertaining way [6].

In the field of English as foreign language education (EFL), there is no exception in efforts to integrate technology into the field of language learning and teaching [7]. With the development of the ICT industry, interest in mobile learning in the field of English teaching and learning is growing, and research is also being actively conducted [8-10]. As a result, the extensive use of technology-integrated instruction has made it possible for EFL learners to experience the diverse capabilities of technology in their language learning [11]. One of the most valuable affordances of mobile phones is situated learning [12]. In situated language learning environment, language learners can act as active constructors of their own knowledge as they learn to understand their own needs and develop learning styles and strategies. English communicative competence is best acquired within authentic contexts, in which students can be involved in realistic language learning tasks [13]. Technology-integrated instruction can help the students focus on the situated learning context in language learning and knowledge construction. Integrating language learning activities into real-world settings holds the potential to make learning more relevant and enjoyable [14]. With the more learner-centered innovative approaches of new technologies, language learners can have opportunities to achieve communicative competence while engaging in authentic communication in relevant and meaningful contexts [15]. Utilizing digital devices can support language learners in acquiring communicative competence to meet their learning needs and to engage them in authentic communication from meaningful and sustainable perspectives.

Incorporating digital devices, such as mobile phones or pads, into the language learning process has potential as an innovative language learning and teaching method due to several aspects, such as portability, agility, and connectivity [16]. As using mobile phones has become an integral part of everyday life for most college students, educators and researchers have been scrutinizing how to integrate digital smart devices into classroom procedures. The widespread use of smartphones among college students has prompted teachers to explore how this digital technology can help enhance learning motivation and maintain students' sustainable learning experiences [17].

The objective of this study was to investigate the impact of utilizing mobile-assisted language learning in helping EFL University students promote their learning performance and support sustainable self-directed learning experience. The research questions of this study are as follows:

1. What are the perceptions and attitudes of university students about using digital devices and mobile applications to study English?

2. How does the integration of mobile applications help students to develop digital literacy and technology competence?

3. How can mobile-assisted language learning facilitate the sustainable self-directed learning experience of university students? 


\section{Related Research}

With the growth of information and communication technology, technology-enhanced language learning has been increasingly regarded as a successful way to support learners with more interconnecting and collaborative language learning environments. Since smartphones have recently become an indispensable item in modern society, mobile-assisted language learning (m-learning) has been introduced to assist students' language learning with the convenient features of digital devices and mobile technologies [6,18]. In particular, in the situation in which schools have been shut down due to the global COVID-19 pandemic and the sustainability of education has been threatened, the role of m-learning becomes even more important to provide quality education to students outside of school and help them to continue their self-directed learning. Self-directed learning is the concept of autonomous learning outside the classroom dimension [19]. When schooling is threatened and too limited to allow meaningful learning to happen, as it is today, it is crucial to utilize the alternative educational resources available outside the classroom. The accessibility and flexibility of the mobile-assisted language learning environment provides students with more authentic learning opportunities, making it easier to adapt to unfamiliar learning experiences. This is why technology-enhanced m-learning is inevitable for sustainable self-directed learning [20]. M-learning can support students to develop digital literacy and technology competence. It also provides a learner-centered and self-directed learning environment where learning is autonomous and sustainable [21].

The ICT Development Index (IDI) is a composite index with 11 indicators combined into a composite score. It is used to monitor and compare developments in information and communication technology between countries over time. According to the International Telecommunication Union (ITU) report, South Korea placed 1st in the IDI (ICT Development Index) ranking among 147 countries in 2016 and 2nd out of 176 countries in 2017 [22]. Korea also shows higher levels of ICT accessibility, network infrastructure, ICT intensity of society, and ICT influence in digital literacy. Korea ranks first in the world for smartphone ownership and internet use. Nine out ten Korean adults make use of the internet and own a smartphone. Korea is also known as the country with the best internet connection in the world. It showed the highest internet penetration rate at 96 percent followed by the Netherlands and Australia (both at 93 percent) [23]. According to the report by the US-based Pew Research Center, South Korea recorded the highest smartphone ownership rate of 94 percent followed by Israel (83 percent) and Australia (82 percent) as seen in Figure 1 below [23].

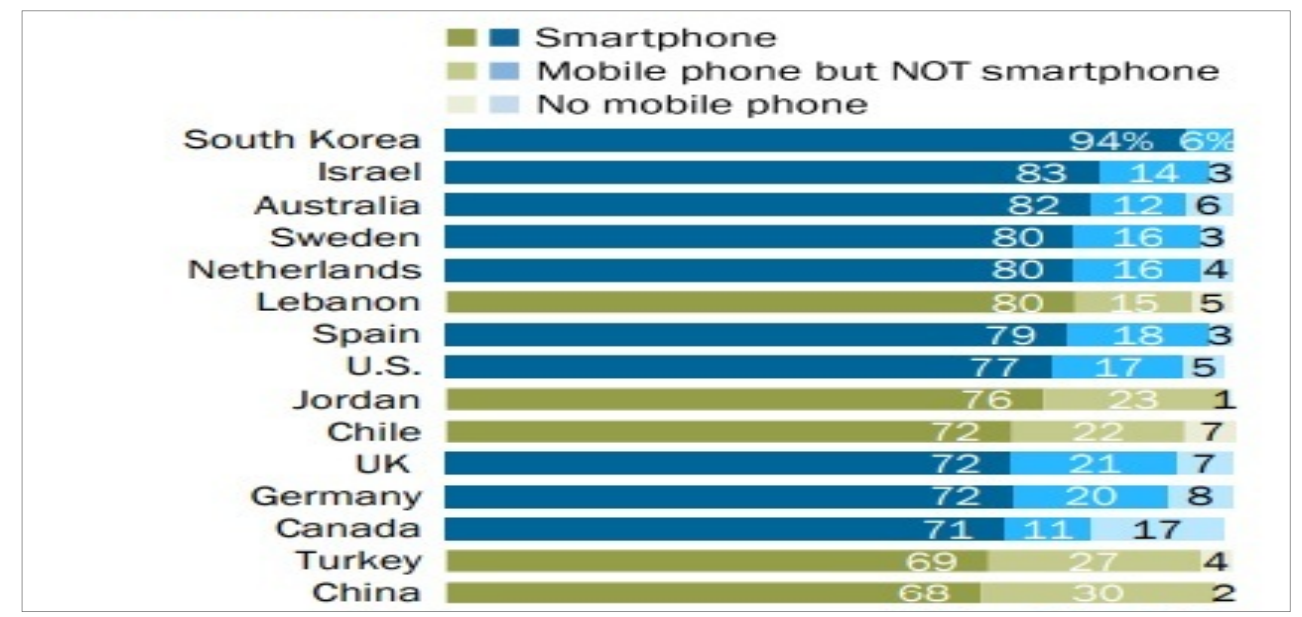

Figure 1. Global divide on smartphone ownership.

As can be seen from Figure 2 below, this statistic shows the smartphone ownership rate of internet users in Korea as of September 2020 by age group. It shows that $99 \%$ of 
people aged 20-59 have smartphones and utilize the internet, and 94.7\% aged 6-19 and 93.1\% aged 60-69 have smartphones and utilize the internet [24].

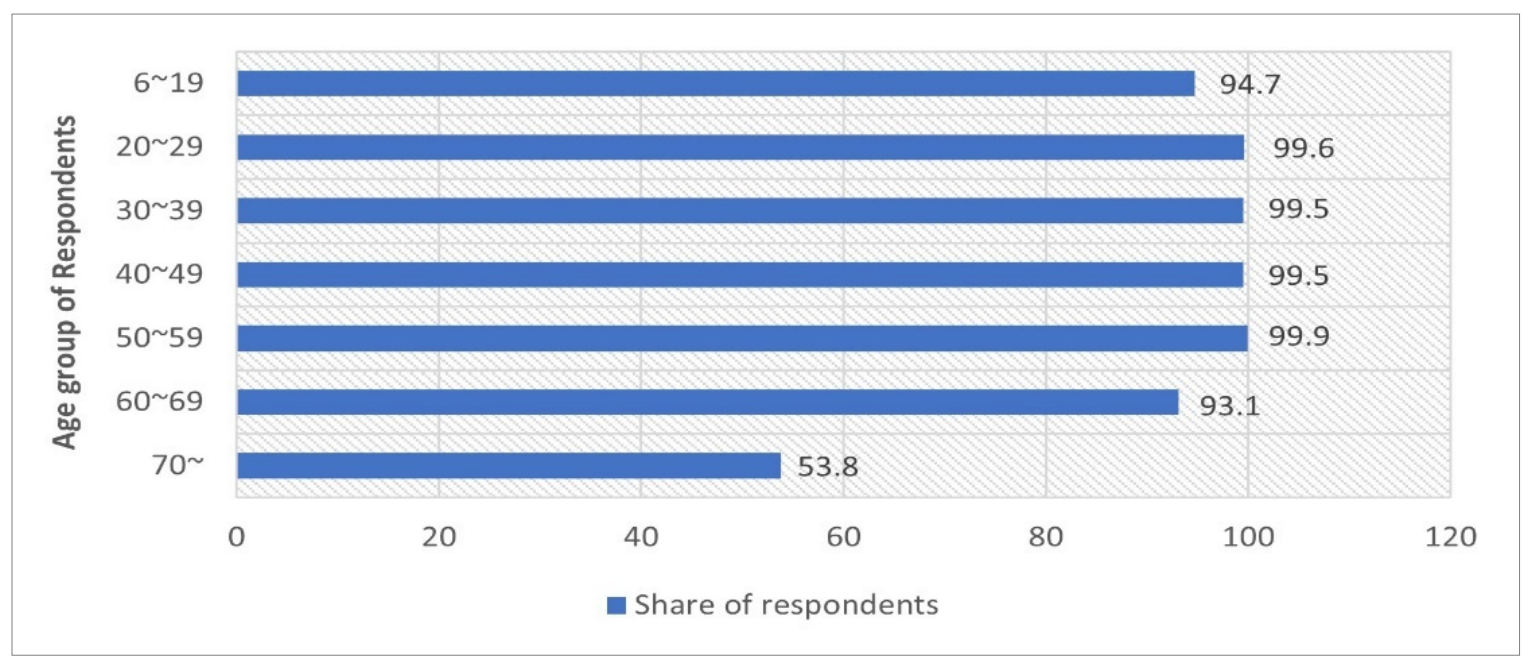

Figure 2. Smartphone ownership South Korea 2020, by age group.

For university students in particular in South Korea, the use of digital technology and smartphones has become an inseparable part of their daily activities. Hence, instructors at college have investigated teaching methods to transform their students' enthusiasm for using digital devices into a pedagogic paradigm. Researchers and instructors have also investigated educational designs that can leverage the beneficial elements of smartphone applications to tailor the needs and interests of tech-savvy, digitally native college students. Thanks to the all-encompassing capabilities of smartphones, mobile learning has become a prominent element of the e-learning movement. Smartphone integration gives students easy access to language learning resources and allows them to interact with teachers and fellow students whenever and wherever they want [25]. Smartphones can be useful and convenient learning tools in language education because they have features such as Internet connectivity, voice and text messaging, and audiovisual recording capabilities. All the characteristics of mobile phones can be successfully implemented in the learning and teaching of a new language. Table 1 classifies the characteristics of mobile learning into six categories [20].

Interrelated factors, such as learner characteristics, teachers' educational beliefs, the context of a particular course, and learning assessment, have played an essential role in the success of mobile learning. The most important characteristics of mobile learning are accessibility, mobility, interactivity, and flexibility [26]. Smart education has the advantage of allowing users to access the Internet anytime, anywhere using digital devices such as mobile phones and tablets, and this enables language learners to choose the learning contents and learning environment that suit their learning style and strategy. Most digital devices are equipped with innovative and cutting-edge technologies, such as high-quality camera features, voice recording capabilities, good storage capacity, proper screen sizes, and a longer battery life, so language educators have been working to increase the use of technology in the classroom [27]. In addition, these days, it is possible for learners to perform various language learning activities, such as language dictionary searches, translation, real-time tutoring, and recording using various mobile applications. These features are attracting attention as useful smart learning tools that can increase the efficiency of foreign language learning because they allow learners to consume the necessary language learning contents at their own pace [28]. 
Table 1. Features of mobile learning.

\begin{tabular}{|c|c|}
\hline Features & Contents \\
\hline \multirow{4}{*}{ Flexibility and easy access to resources } & $\begin{array}{l}\text { Learning function through free movement without } \\
\text { space restrictions }\end{array}$ \\
\hline & $\begin{array}{l}\text { Expanding learning places and } \\
\text { experience opportunities }\end{array}$ \\
\hline & $\begin{array}{l}\text { Fast and flexible access to a variety of } \\
\text { learning resources }\end{array}$ \\
\hline & $\begin{array}{l}\text { Timely learning is possible with instant access to the } \\
\text { desired learning materials }\end{array}$ \\
\hline \multirow[t]{2}{*}{ Individualized learning topic } & $\begin{array}{l}\text { Customized learning tailored to the characteristics of } \\
\text { the learners }\end{array}$ \\
\hline & Personalized learning that meets the needs of learners \\
\hline \multirow{3}{*}{ Simplicity of learning content } & $\begin{array}{l}\text { Systematic, structured, simplified, and modularized } \\
\text { learning contents }\end{array}$ \\
\hline & $\begin{array}{l}\text { Provide learning focusing on concise and condensed } \\
\text { core contents }\end{array}$ \\
\hline & Changes in tools and methods of interaction \\
\hline Interactivity with learning objects & $\begin{array}{l}\text { Cooperative learning possible through } \\
\text { immediate interactions }\end{array}$ \\
\hline & $\begin{array}{l}\text { Able to perform learning activities in real situations } \\
\text { or contexts }\end{array}$ \\
\hline Contextuality of learning activities & $\begin{array}{l}\text { Integration of theoretical learning contents and } \\
\text { practical experience }\end{array}$ \\
\hline
\end{tabular}

Digital devices can only make students' language learning experience itself truly mobile when language teachers are able to make use of creative learning tasks that allow their students' learning experience to extend beyond the classroom. With such instructional strategies, students expressed their enjoyment of being able to learn and practice a language outside of the classroom with the support of mobile phones [29]. Mobile learning can provide students with a more exciting learning environment. It can also allow students to collaborate with immediate feedback, dynamic classroom interactions, and improved learning outcomes [30]. Other research has shown that the integration of mobile phones and digital applications into EFL education can improve EFL learners' speaking, reading, grammar, and writing skills [5,31]. To develop EFL students' English communication competence and to guarantee sustainable self-directed learning experiences, smart technologies should be integrated into existing educational curricula to create more opportunities for authentic social interaction and meaningful negotiation experiences [32].

\section{Research Context and Methods}

\subsection{Research Subjects}

The participants of this study included 62 university students from the middle region of South Korea who were enrolled in a general English course. Among them, two students who did not respond to the questionnaire were excluded from the study. The gender and majors of a total of 60 participants are given in Table 2.

Table 2. Participant distribution $(\mathrm{N}=60)$.

\begin{tabular}{cccc}
\hline & Majors & N & \% \\
\hline \multirow{3}{*}{ Department } & Language and Literature & 9 & 15.0 \\
& Philosophy & 8 & 13.3 \\
& History & 12 & 20.0 \\
& Electronic Engineering & 18 & 30.0 \\
& Mechanical Engineering & 13 & 21.7 \\
\hline \multirow{2}{*}{ Gender } & Male & 42 & 70.0 \\
& Female & 18 & 30.0 \\
\hline
\end{tabular}




\subsection{Research Context}

Since this study was a three-credit general English course, classes were held twice a week, and each class was 90 min long. The students' English proficiency level was at the low-intermediate level. The objective of this English course was to enhance students ${ }^{\prime}$ English communication skills and help them develop learning strategies for self-study in English. In Korea, the Test of English for International Communication (TOEIC) score is used as an important tool to evaluate English proficiency and is used to verify a candidate's language ability in the job market or promotion in the workplace. Therefore, high TOEIC scores allow for mobility in class movement in society. In some cases, TOEIC scores above a certain level are required as a graduation condition, and TOEIC scores have a significant impact on career paths after graduation for the university students, so improving test scores was important for students. However, since improving TOEIC test scores was not the primary goal of the course, the instructor decided to incorporate the use of mobile application programs as part of the course to provide students with the opportunity to improve their TOEIC test scores through self-study outside of classroom instruction. As a hybrid m-learning course, the participants were required to use a digital device such as a mobile phone or pad to download and access a mobile application. Through a free mobile application called Hackers TOEIC, m-learning was conducted for one semester as a part of the general English class, and in the 15th week, post-experience of application utilization was surveyed by questionnaire at the end of the semester. For self-directed m-learning practice, participating students were required to log into the mobile application and study the vocabulary, listening, and reading sections of the TOEIC, which were updated daily in the mobile application. Figure 3 shows the mobile-assisted language learning activities that allow students to self-study outside the classroom using the mobile application.
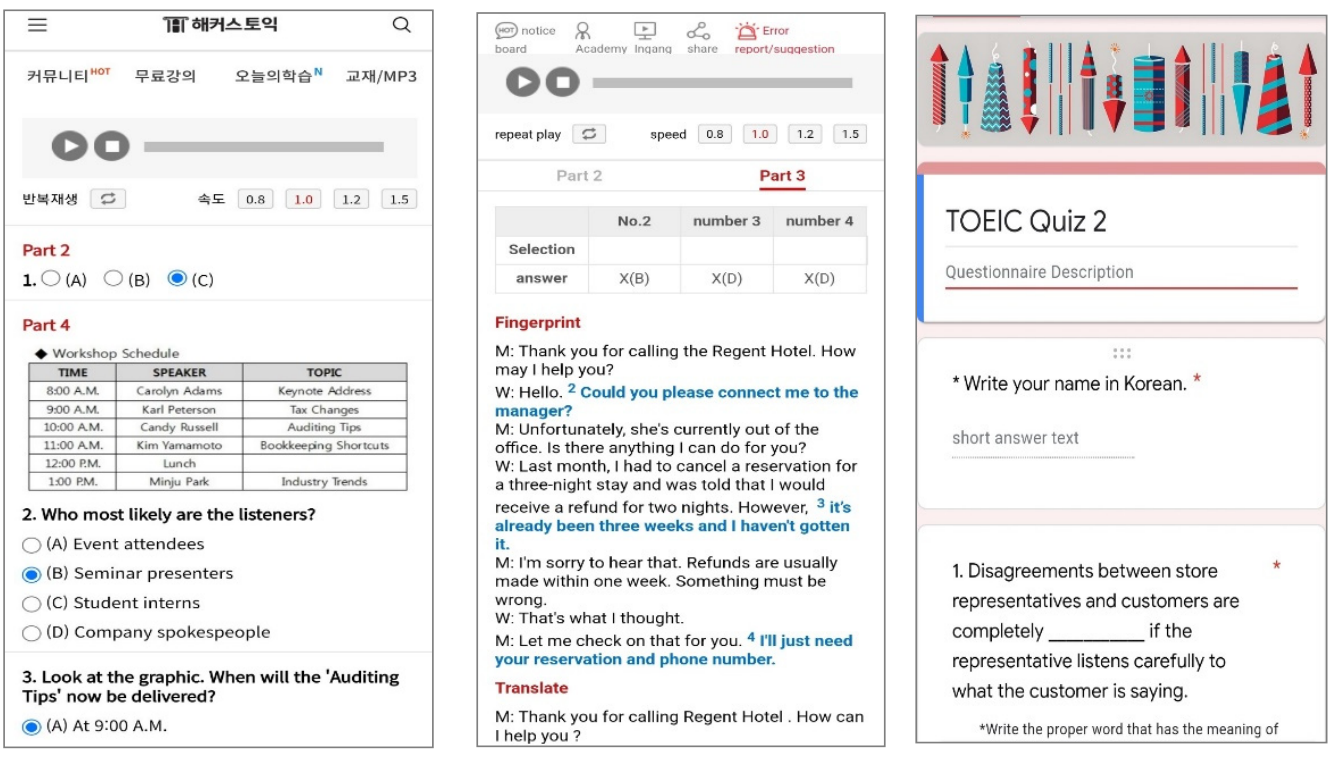

Figure 3. Mobile learning for students' self-study.

During the experimental period, students were asked to study the TOEIC reading part and listening part, each consisting of 5 questions, using a self-study mobile application to stimulate and motivate them. When students accessed the mobile application to study online learning contents, they were required to submit a summary. They were required to upload what they had learned to the course LMS each week. While solving the problems, the students reviewed and studied important vocabulary, sentences, grammar elements, and pronunciation. In class, the instructor checked and monitored students' learning logs and briefly discussed common challenges most students had faced when using mobile applications for self-directed learning. Once a week, the instructor provided online quizzes on TOEIC self-study using Google test forms so that students could check and reflect on 
what they had learned through self-directed m-learning. As soon as students took the online quiz using their mobile phones and submitted their answers on their mobile phones, the instructor used an instant-grading program to provide immediate feedback on the quiz.

\subsection{Data Collection and Analysis}

In this study, data were collected from a variety of sources. The effect of self-directed m-learning was investigated by conducting pre- and post-tests using the abridged version of TOEIC. The short version of the TOEIC test consisted of a total of 40 questions, with 20 questions each in the listening part and reading part of the TOEIC test. Test performance data were analyzed using the SPSS 24 trial. In addition, two online surveys were conducted through the Google survey form. In this study, the pre- and post-questionnaire items were partially reconstructed with reference to the questionnaire items used in the study of Kim [20]. The first online pre-questionnaire survey was conducted at the beginning of the semester to find out whether learners had prior experience of learning English using mobile phones and self-evaluation related to learning English. It consisted of 8 multiple choice questions with the five Likert-scales (highly disagree as 1 and highly agree as 5) and 2 open-ended questions. At the end of the semester, the online post-questionnaire survey was conducted to examine students' motivation and perception about the effectiveness, relevance, satisfaction, and usefulness of using mobile applications in self-directed m-learning. In addition, semi-structured focus group interviews were conducted with volunteer students. The post-questionnaire survey was composed of 18 multiple-choice items with the five-point Likert scale and 2 open-ended questionnaire items. In order to obtain more reliable survey results, the anonymity of the respondents was guaranteed in the survey. In consideration of ethical concerns, informed consent from study participants was obtained. The purpose of the study was introduced in advance, and the consent was obtained via a question asking whether or not students wished to participate in the research included in the questionnaire survey. The survey data were analyzed using Google Forms' automatic statistics feature. Five of the participants voluntarily participated in a semi-structured focus group interview about their perceptions and motivations for engaging in self-directed mobile learning. Open-ended questionnaire items and semi-structured interview data were analyzed and interpreted in terms of effectiveness, utilization, satisfaction, and usefulness of mobile-assisted language learning.

\section{Results}

\subsection{The Effect of Mobile-Assisted Language Learning on Students' Learning Performance}

At the beginning of the semester, the pre-questionnaire survey was conducted to find out students' self-evaluation related to learning English. Figure 4 shows the participants' responses to the questionnaire item "Do you think your general English level is good?". The result shows that only $5 \%$ of the students answered that they thought they were good at English and 25\% of the students answered that they were not good at English at all. This result signifies that more than half of the students perceived their English proficiency level as low-intermediate.

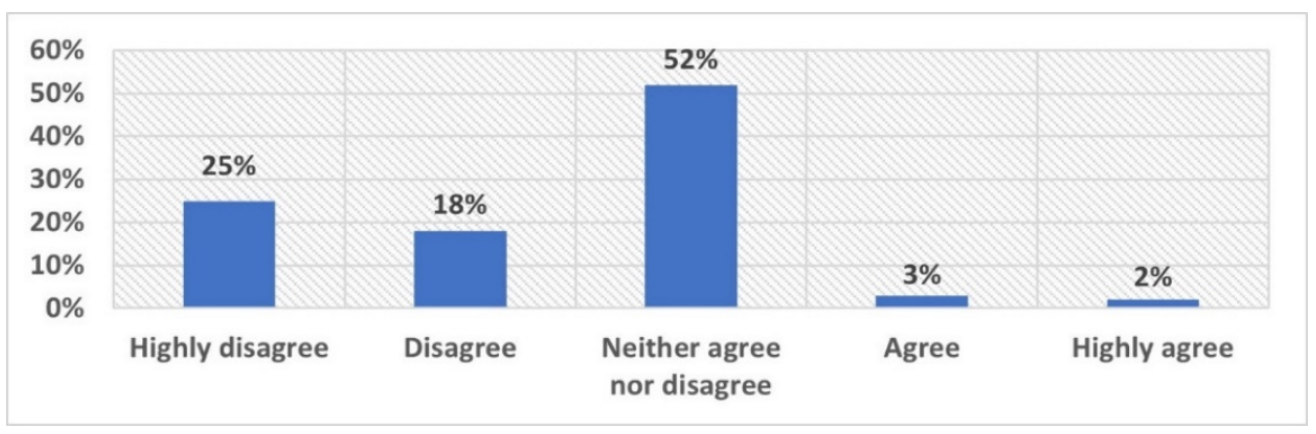

Figure 4. Students' responses to the perceived English proficiency level. 
Figure 5 shows the participants' responses to the questionnaire item "Which of the four English skills are you most confident in?". According to the survey results, the English skill that students were most confident in was reading, and the most difficult one was writing.

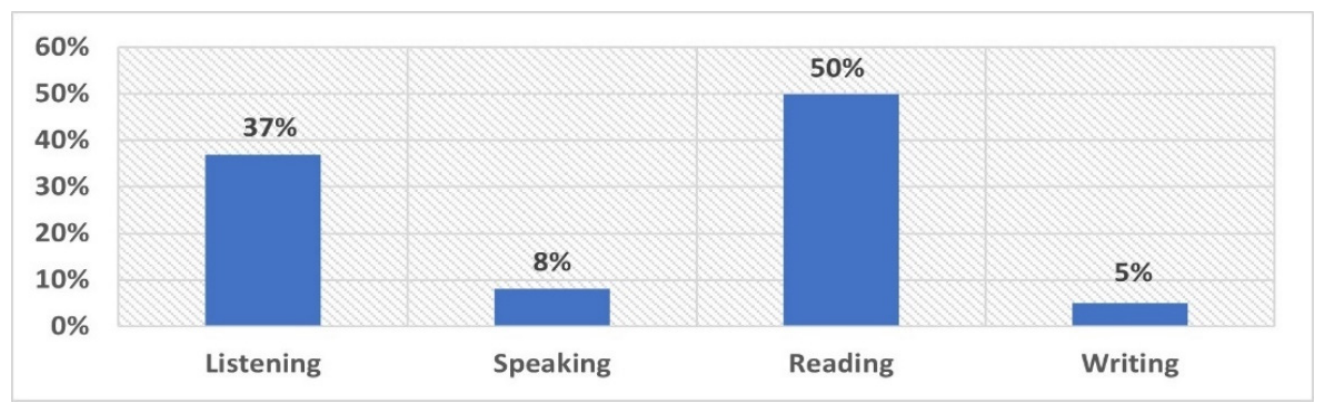

Figure 5. Students' response to the perceived confidence level of four English language skills.

The preliminary test to determine the students' English introductory level was an abridged version of the TOEIC test consisting of 40 questions from listening part 2 and 3 and reading part 5 and 6 of the TOEIC test. It was administered in the second week of the semester. In order to examine the effect of self-directed m-learning using a mobile application, students took the same type of post-test at the end of the semester to check the exit level of English proficiency. Table 3 shows the scoring results of the pre- and post-listening tests indicating whether or not students' listening ability had improved.

Table 3. The results of pre-test and post-test of listening part.

\begin{tabular}{ccccccc}
\hline \multicolumn{2}{c}{ Test } & Mean & N & SD & $t$ & $p$ \\
\hline \multirow{2}{*}{$\begin{array}{c}\text { Listening } \\
\text { Part }\end{array}$} & Pre-test & 15.54 & 60 & 2.711 & & \multirow{2}{*}{2.555} \\
\cline { 2 - 5 } & Post-test & 16.25 & 60 & 2.811 & & $0.013 *$ \\
$* p<0.05$. & & & & &
\end{tabular}

As a result of the independent samples $t$-test, in the TOEIC listening part, the average score of the pre-test was 15.54 and the average score of the post-test was 16.25. There was a 0.71-point increase in the listening mean score between the pre-test and the post-test, with a statistically significant difference. This result could indicate that the use of the mobile application had a positive effect on students' TOEIC listening study through self-directed mobile learning outside the classroom.

Table 4 shows the scoring results of the pre- and post-reading tests indicating whether or not students' reading ability had improved.

Table 4. The results of pre-test and post-test of reading part.

\begin{tabular}{ccccccc}
\hline \multicolumn{2}{c}{ Test } & Mean & N & SD & $t$ & $p$ \\
\hline Reading & Pre-test & 14.93 & 60 & 2.633 & -1.212 & 0.230 \\
Part & Post-test & 15.24 & 60 & 2.362 & & \\
\hline$p<0.05$ & & & &
\end{tabular}

As a result of the independent samples $t$-test, in the TOEIC reading part, the average score of the pre-test was 14.93 and the average score of the post-test was 15.24. There was a 0.31 -point increase in the reading mean score between the pre-test and the posttest. According to the results of an independent samples $t$-test, there was no statistically significant difference in the TOEIC reading part between the pre-test scores and post-test scores. Based on the preliminary survey results, in which students responded that they were more proficient in reading than listening, it can be inferred that students spent more time and effort studying the area in which they needed to improve, listening. Even though there was no noticeable difference in using smart applications for studying the TOEIC 
reading part, it can be said that students' reading ability slightly improved to some extent by repeatedly studying the reading part and acquiring important vocabulary, sentence reading, and grammar.

\subsection{Students' Perceptions and Attitudes toward Mobile-Assisted Language Learning}

At the end of the semester, the post-questionnaire survey was conducted to examine students' perception and attitudes toward the effectiveness, relevance, satisfaction, and usefulness of using mobile applications in their self-directed m-learning. As a result of the survey shown in Table 5, students answered that self-directed learning using mobile applications was an overall positive and motivating learning experience. Of the 60 students, $49(82 \%)$ said that they enjoyed studying English using the mobile application for their self-study $[20,24]$.

Table 5. Students' responses to the enjoyable aspect of mobile-assisted language learning.

\begin{tabular}{cccccc}
\hline \multicolumn{5}{c}{ I Enjoyed Studying English Using Mobile Application Using Digital Devices } \\
\hline & Strongly Disagree & Disagree & Neutral & Agree & Strongly Agree \\
\hline Frequency & 0 & 2 & 9 & 27 & 22 \\
\hline Percent & $0 \%$ & $3 \%$ & $15 \%$ & $45 \%$ & $37 \%$ \\
\hline
\end{tabular}

As shown in Table 6, 43 students (72\%) of the 60 respondents said that studying English through a mobile application was more attractive than traditional learning methods. These results are consistent with other research findings that, when digital devices are integrated into language learning, students preferred mobile-based learning over traditional learning methods because of a more convenient and interesting learning environment $[28,29,33]$.

Table 6. Students' responses to traditional vs. mobile-assisted language learning.

\begin{tabular}{cccccc}
\hline \multicolumn{5}{c}{ Mobile-Assisted Language Learning Was More Attractive Than Traditional Learning Format } \\
\hline & Strongly Disagree & Disagree & Neutral & Agree & Strongly Agree \\
\hline Frequency & 1 & 3 & 13 & 18 & 25 \\
\hline Percent & $2 \%$ & $5 \%$ & $21 \%$ & $30 \%$ & $42 \%$ \\
\hline
\end{tabular}

As a result of the survey shown in Table 7, of the participants, 43 (72\%) answered that studying with a mobile application was helpful for their TOEIC listening studies. These responses are compatible with the research results that show the use of mobile applications had a significant effect on pre- and post-test improvement in TOEIC listening skills [34]. The very positive results of participants' perceptions of the integration of mobile applications into their language learning suggest that mobile-assisted learning may have a potential effect as a sophisticated learning device on students' self-directed learning.

Table 7. Students' responses to effect of m-learning on improving TOEIC listening skill.

\begin{tabular}{cccccc}
\hline \multicolumn{5}{c}{ Studying with Mobile App Was Helpful for TOEIC Listening Study } \\
\hline & Strongly Disagree & Disagree & Neutral & Agree & Strongly Agree \\
\hline Frequency & 0 & 1 & 16 & 16 & 27 \\
\hline Percent & $0 \%$ & $2 \%$ & $26.5 \%$ & $26.5 \%$ & $45 \%$ \\
\hline
\end{tabular}

According to Table 8 below, it is meaningful that 40 students, $66 \%$ of the total respondents, answered that studying through the mobile application was helpful for TOEIC reading study. Although it was found that studying using the mobile application did 
not have a statistically significant effect on students' TOEIC reading pre- and post-test results, it suggests that students had positive perceptions and attitudes toward using mobile applications for TOEIC reading study [24].

Table 8. Students' responses to effect of m-learning on improving TOEIC reading skill.

\begin{tabular}{cccccc}
\hline \multicolumn{5}{c}{ Studying with Mobile App Was Helpful for TOEIC Reading Study } \\
\hline & Strongly Disagree & Disagree & Neutral & Agree & Strongly Agree \\
\hline Frequency & 0 & 4 & 16 & 23 & 17 \\
\hline Percent & $0 \%$ & $7 \%$ & $27 \%$ & $38 \%$ & $28 \%$ \\
\hline
\end{tabular}

According to Table 9 below, 42 students, $70 \%$ of the total respondents, responded that mobile-assisted language learning was a very successful instructional method in promoting their learning motivation and self-directed study experience. Most of the participants showed a positive reaction to learner-centered autonomous learning and reinforcement of learning motivation using the TOEIC application on their mobile phones. Considering the aspect of self-directed learning outside of class time without the help of the instructor, it is considered to have significant implications.

Table 9. Students' response to learning motivation and self-directed learning experience.

\begin{tabular}{cccccc}
\hline \multicolumn{5}{c}{ Studying Using the Mobile App Has Been a Great Motivation for My Self-Study of English } \\
\hline & Strongly Disagree & Disagree & Neutral & Agree & Strongly Agree \\
\hline Frequency & 0 & 5 & 13 & 18 & 24 \\
\hline Percent & $0 \%$ & $8 \%$ & $22 \%$ & $30 \%$ & $40 \%$ \\
\hline
\end{tabular}

According to open-ended questionnaire survey items and semi-structured interviews, participants generally perceived that using a smartphone application as a mobile-based self-learning method was an effective, interesting, convenient, and creative format for improving their English skills. The positive results of learners' perceptions of using mobile applications suggest that mobile-based language learning may have potential as a tool for self-study in their English learning. Therefore, it is necessary for educators to create a learning environment that can increase the correlation between the use of mobile phone applications and class contents $[20,35]$. The participants responded that taking the online quiz on their mobile phone was convenient. They also responded that it was good that they were able to receive immediate test results and feedback as soon as they submitted their answers, which gave them an opportunity to reflect on their own learning. It can be seen that these mobile learning and online quizzes have successfully served as a way to promote the motivation of learners.

The repeated themes from the thematic analysis of qualitative data of the focus group interview were convenience and entertainment. Functionality, along with convenience and entertainment, was one of the biggest factors in determining satisfaction with the use of mobile phone applications and whether participants would continue using them. Students perceived m-learning using mobile phones as an attractive teaching/learning method suitable for the age of digital transformation and answered that they were able to learn autonomously with pleasure. Students in this study reported that the main benefits of studying TOEIC using a mobile application included easy access, convenience, portability, flexible time management, enjoyable learning, and improved self-direction in learning [26]. Some of the comments from respondents include:

I felt it was the right class for the interest of a new generation. This semester, I was able to realize the convenience of the high-tech industry through the experience of using the mobile application as a tool for self-directed learning. It was a new and novel way of teaching. It was very convenient and good to take the quiz on a mobile phone. I felt it was 
efficient because it was possible to reduce the time for distributing test papers or scoring by hand. It was convenient to be able to study for the TOEIC test anytime, anywhere using the mobile application! During the vacation, I plan to use the app that we used this semester for self-taught TOEIC study. (Data from individual interview)

Using the mobile application for self-directed learning was a new experience for me this semester, so I wanted to participate more actively in self-directed learning. Instead of spending the meaningless time in SNS or YouTube, it was nice to be able to conveniently study on my mobile phone while using public transportation for commuting to school. The biggest advantage is that it can be used anytime, anywhere. The time and frequency of accessing TOEIC learning contents has increased compared to studying TOEIC with books. (Data from individual interview)

Some participants also reported that they were not yet used to learning English on a mobile phone due to the small screen size or data problems. Some participants responded that mobile phones were mainly useful for short-term learning 'on the go', not for long-term learning that required concentration. They also said that while learning English using a free mobile application was a good experience, they would not actively use their phone to the point of using a paid mobile application for their study. Therefore, it was suggested that active guidance related to class contents is needed in self-directed language learning using mobile phone applications.

\section{Conclusions}

This study explored the impact of utilizing mobile-assisted language learning in helping EFL university students promote their learning performance and support sustainable self-directed learning outside of the classroom. The purpose of this study was first to examine how mobile-assisted self-directed learning affects the English proficiency of EFL university students. This study also tried to investigate participants' perception and attitudes toward their mobile-assisted language learning experience. To examine the effectiveness of mobile-assisted self-learning, pre- and post-TOEIC tests were conducted. Preand post-questionnaire surveys were also conducted to investigate participants' perceptions and attitudes toward their learning experiences of using mobile applications. Regarding the effect of mobile-assisted language learning, which was the first objective of the study, on the TOEIC pre- and post-test scores, there was a significant average improvement in the TOEIC listening ability, and there was an average increase in the TOEIC reading part scores, although there was no significant difference seen. This suggests that the use of mobile phone applications helps to some extent in autonomous and self-directed English learning. In terms of participants' perceptions, as elucidated by the second research question, on self-directed mobile-assisted language learning, most of the participants showed positive responses to self-study using a mobile application.

The results of this study show that the advantageous features of self-directed learning using mobile phone applications included easy access, convenience, portability, flexible time management, and enjoyable learning, and improved self-direction in learning [26]. As a disadvantage, it was pointed out that the continuity and concentration of learning were reduced due to eye fatigue and reduced readability due to the small screen size of their mobile devices [35]. The fact that learners have a positive intention to use mobile phone applications for English learning in the future implies that using mobile phone applications has a potential value for language learners' self-directed learning in making their learning experience more sustainable [36]. Therefore, instructors should make efforts to develop appropriate syllabus designs and teaching strategies to provide their students with a sustainable learning environment and to enable self-directed learning, while making good use of the various advantages of mobile learning and identifying the disadvantages [37]. As implied by the results of this study, when the utilization of mobile applications is applied to provide sustainability in learning and to increase students' motivation and autonomy in learning, mobile-assisted language learning can help improve students' self-directed learning habits [38]. 
Funding: This research received no external funding.

Institutional Review Board Statement: Not applicable.

Informed Consent Statement: Informed consent was obtained from all subjects involved in the study.

Data Availability Statement: Not applicable.

Conflicts of Interest: The author declares no conflict of interest.

\section{References}

1. Nickerson, R.S. Technology in Education in 2020: Thinking about the Not-Distant Future. In Technology in Education: Looking Toward 2020; Nickerson, R.S., Zodhiates, P.P., Eds.; Lawrence Erlbaum Associates: Hillsdale, NJ, USA, 2017; pp. 331-356.

2. Godwin-Jones, R. Smartphones and language learning. Lang. Learn. Technol. 2017, 21, 3-17. Available online: https://scholarspace. manoa.hawaii.edu/bitstream/10125/44607/1/21_02_emerging.pdf (accessed on 17 October 2021).

3. Gay, G.; Stefanone, M.; Grace-Martin, M.; Hembrooke, H. The effects of wireless computing in collaborative learning environments. Int. J. Hum. Comput. Interact. 2001, 13, 257-276. [CrossRef]

4. Wu, Q. Designing a smartphone app to teach English (L2) vocabulary. Comput. Educ. 2015, 85, 170-179. [CrossRef]

5. Chen, C.M.; Hsu, S.H. Personalized intelligent mobile learning system for supportive effective English learning. Educ. Technol. Soc. J. 2008, 11, 153-180.

6. Huang, C.S.J.; Yang, S.J.H.; Chiang, T.H.C.; Su, A.Y.S. Effects of situated mobile learning approach on learning motivation and performance of EFL students. Educ. Technol. Soc. 2016, 19, 263-276.

7. Wang, H.; Chen, C.W. Learning English from YouTubers: English L2 learners' self-regulated language learning on YouTube. Innov. Lang. Learn. Teach. 2020, 14, 333-346. [CrossRef]

8. Cavus, N. Development of an intelligent mobile application for teaching English pronunciation. Procedia Comput. Sci. 2016, 102, 365-369. [CrossRef]

9. Sung, Y.; Chang, K.; Yang, J. How effective are mobile devices for language learning? A Meta-Anal. Educ. Res. Rev. 2015, 16, 68-84. [CrossRef]

10. Kukulska-Hulme, A. Will mobile learning change language learning? ReCALL 2009, 21, 157-165. [CrossRef]

11. Rosell-Aguilar, F. Autonomous language learning through a mobile application: A user evaluation of the busuu app. Comput. Assist. Lang. Learn. 2018, 31, 854-881. [CrossRef]

12. Lave, J.; Wenger, E. Situated Learning: Legitimate Peripheral Participation; Cambridge University Press: Cambridge, UK, 1991.

13. Felix, U. The web as a vehicle for constructivist approaches in language teaching. ReCALL 2002, 14, 2-15. [CrossRef]

14. Traxler, J. Sustaining Mobile Learning and its Institutions. Int. J. Mob. Blended Learn. 2010, 2, 58-65. [CrossRef]

15. Kukulska-Hulme, A.; Viberg, O. Mobile collaborative language learning: State of the art. Br. J. Educ. Technol. 2018, 49, 207-218. [CrossRef]

16. Al-Shehri, S. Context in our pockets: Mobile phones and social networking as tools of contextualizing language learning. In Proceedings of the 10th World Conference on Mobile and Contextual Learning (mLearn), Beijing, China, 18-21 October 2011.

17. Cavus, N.; Ibrahim, D. M-learning: An experiment in using SMS to support learning new English language words. Br. J. Educ. Technol. 2009, 40, 78-91. [CrossRef]

18. Thorton, P.; Houser, C. Using mobile phones in English education in Japan. J. Comput. Assist. Learn. 2005, 21, 217-228. [CrossRef]

19. Nunan, D. Teaching English to Speakers of Other Languages; Routledge: New York, NY, USA, 2015.

20. Kim, M. Students' Perceptions of the Effectiveness of Using Mobile Application (CAKE) in College English Course. J. Educ. Dev. 2021, 41, 83-105. [CrossRef]

21. Sert, N.; Boynuegri, E. Digital technology use by the students and English teachers and self-directed language learning. World J. Educ. Technol. Curr. Issues 2017, 9, 24-34. [CrossRef]

22. ITU. Measuring the Information Society Report 2017. Available online: https://www.itu.int/en/ITU-D/Statistics/Pages/ publications / mis2017.aspx (accessed on 14 November 2021).

23. Sohn, J. Korea No. 1 Worldwide in Smartphone Ownership, Internet Penetration. The Korea Herald, 24 June 2018. Available online: http: / / www.koreaherald.com/view.php?ud=20180624000197 (accessed on 14 November 2021).

24. Yoon, J. Smartphone Ownership South Korea 2020, by Age Group. Statista, 21 April 2021. Available online: https:/ /www.statista. com/statistics/897195/south-korea-smartphone-ownership-by-age-group (accessed on 14 November 2021).

25. Zhao, Y. The future of research in technology and second language education. In Research in Technology and Second Language Learning: Developments and Directions; Information Age Publishing: Greenwich, CT, USA, 2005.

26. Miangah, T.M.; Nezarat, A. Mobile-assisted language learning. Int. J. Distrib. Parallel Syst. 2012, 3, 309-319. [CrossRef]

27. Godwin-Jones, R. Emerging technologies mobile apps for language learning. Lang. Learn. Technol. 2011, 15, 2-11.

28. Kim, H.; Kwon, Y. Exploring smartphone applications for effective mobile-assisted language learning. Multimed. Assist. Lang. Learn. 2012, 16, 31-57.

29. Dudeney, G.; Hocky, N. Blended learning in a mobile context: New tools, new learning experiences? In Blended Learning for Language Teaching; McCarthy, M., Ed.; Cambridge University Press: Cambridge, UK, 2016. 
30. Jia, J.; Chen, Y.; Ding, Z.; Ruan, M. Effects of a vocabulary acquisition and assessment system on students' performance in a blended learning class for English subject. Comput. Educ. 2012, 58, 63-76. [CrossRef]

31. Khoshnoud, K.; Karbalae, A. The effect of interaction through social networks sites on learning English in Iranian EFL context. J. Adv. Engl. Lang. Teach. 2014, 2, 27-33.

32. Jeong, K. Integrating a web-based platform to promote creativity and authenticity in language classrooms. Int. J. Knowl. Learn. 2016, 11, 127-136. [CrossRef]

33. Andujar, A.; Salaberri-Ramiro, M.S. Exploring chat-based communication in the EFL class: Computer and mobile environments. Comput. Assist. Lang. Learn. 2019, 34, 434-461. [CrossRef]

34. Kim, H.S. Using short message service for vocabulary learning by students' English proficiency. Multimed. Assist. Lang. Learn. 2012, 15, 75-96.

35. Song, E. The effects of TOEIC study using smartphone TOEIC applications on learners' TOEIC scores and perception at university level. J. Korea Engl. Educ. Soc. 2013, 12, 49-67. [CrossRef]

36. Al-Rahmi, A.M.; Al-Rahmi, W.M.; Alturki, U.; Aldraiweesh, A.; Almutairy, S.; Al-Adwan, A.S. Exploring the Factors Affecting Mobile Learning for Sustainability in Higher Education. Sustainability 2021, 13, 7893. [CrossRef]

37. Al-Adwan, A.S.; Al-Adwan, A.; Berger, H. Solving the mystery of mobile learning adoption in higher education. Int. J. Mob. Commun. 2018, 16, 24-49. [CrossRef]

38. Lai, Y.; Saab, N.; Admiraal, W. University students' use of mobile technology in self-directed language learning: Using the integrative model of behavior prediction. Comput. Educ. 2022, 179, 104413. [CrossRef] 